\title{
Why do entrepreneurs leave the market? An explanation from experimental economics in Peru ${ }^{\ddagger}$
}

\author{
José Carlos Raunelli* \\ Mauricio Power ${ }^{* *}$ \\ FrANCISCO GALARZA $^{* * *}$
}

\begin{abstract}
Understanding the behavior of those who start--or intend to start--a business is vital for a country of entrepreneurs such as Peru, which registered the third highest rate of active entrepreneurship worldwide in 2011, according to the Global Entrepreneurship Monitor (GEM). However, Peru also registered, in 2011, one of the highest business discontinuation rates among efficiency-based and resource-based economies. This study represents the first effort to analyze certain behavioral characteristics (risk aversion, joy of winning, overconfidence and tax collection) of a sample of necessity-driven entrepreneurs in Lima, Peru. These features might help explain, in the first place, the decision to become entrepreneurs, but also the decision to leave the market. In particular, we find that entrepreneurs are risk averse, tend to overestimate their abilities and are willing to work harder when the gross pay is higher (and are taxed) than when it is lower (and are not taxed). Altogether, these traits may explain the high discontinuation rate of businesses in Peru, one of the highest in efficiency-based and resource-based economies.
\end{abstract}

Keywords: Entrepreneurs, business discontinuation, risk preferences, joy of winning, overconfidence, market entry, taxes, experimental economics, Peru.

JEL Codes: L10, N80, O15

$\ddagger$ This article is a revised version of "Characterizing necessity-driven entrepreneurs in Lima: An approach using field experiments", CIUP Discussion Paper No. 13-04, 2013.

* E-mail: jose.raunelli@gmail.com.

** E-mail: luismauricio.power@gmail.com.

*** (Corresponding author) Department of Economics, Universidad del Pacífico. Av. Salaverry 2020, Jesús María, Lima 11, Peru. Telephone: (51-1) 219-0100 (Ext. 2338), Fax: (51-1) 219-0135. E-mail: galarza_ fb@up.edu.pe. 


\title{
¿Por qué los emprendedores salen del mercado? Una explicación desde la economía experimental en el Perú
}

\begin{abstract}
RESUMEN
Entender el comportamiento de aquellos que empiezan —o pretenden empezar — un negocio es vital para un país de emprendedores así como el Perú, el cual registró la tercera tasa más alta de emprededeurismo activo a nivel mundial en 2011, de acuerdo con el Global Entrepreneurship Monitor (GEM). Sin embargo, el Perú también registró, el año 2011, una de las tasas más altas de descontinuación de negocios entre las economías basadas en la eficiencias y recursos. Este estudio representa el primer intento en analizar ciertas características de conducta (aversión al riesgo, alegría por el triunfo, confianza excesiva y el pago de impuestos) de una muestra de emprendedores motivados por la necesidad en Lima, Perú. Estas características puede que ayuden a explicar, en primer lugar, la decisión de devenir emprendedores, pero también la decisión de dejar el mercado. En particular, nos encontramos con que los emprendedores son adversos al riesgo, tienden a sobrestimar sus habilidades y están dispuestos a trabajar más duro cuando el pago bruto es mayor (y está sujeto a impuestos) que cuando es menor (y no está sujeto a impuestos). En suma, estas características pueden explicar la alta tasa de descontinuación de negocios en el Perú, una de las más altas en economías basadas en la eficiencia o en recursos.
\end{abstract}

Palabras clave: Emprendedores, descontinuación de negocios, preferencias de riesgo, alegría de ganar, exceso de confianza, entrada al mercado, impuestos, economía experimental, Perú.

Clasificación JEL: L10, N80, O15

Recognition of unobservable processes is essential for the growth of our understanding of social phenomena; we must strive to not exclude these processes in our research, if we are to have any hope of understanding the results inside and outside the laboratory (Smith, 2002)

\section{INTRODUCTION}

One out of four people has an entrepreneurial activity in Peru, which puts the country in the third place among the group of economies motivated by efficiency. ${ }^{1}$ Peru also shows the greatest entrepreneurial activity rate $(22.9 \%)^{2}$, the second largest rate of entrepreneurial activity with innovative products (and the third largest, globally),

1 The Global Entrepreneurship Monitor (GEM) divides the set of economies studied in three subgroups: Economies based on Innovation, on Efficiency and on Resources. Peru is categorized within the second group, which takes advantage of their country's economic growth to provide services to the industrial sector or provide consumer goods to a population with higher levels of per capita income.

2 The entrepreneurial activity rate, also known as the TEA index (Total Early Stage Entrepreneurship Activity), measures the quantity of people, between ages 18 and 64 (working ages), that are actively involved in the creation of a business since the very beginning or are owners of a new one (Serida, Morales, \& Nakamatsu, 2012). 
has the highest expected entrepreneurial growth $(26 \%)$ and is the fifth country, within its group, with the highest entrepreneurial intentions in a survey to non-entrepreneurs (37.5\%) (Serida, Morales, \& Nakamatsu, 2012).

However, while being one of the most entrepreneurial countries in the world, there is a dark side: $5.1 \%$ of all enterprises do not continue. This number may not seem very high, but it was above the average rate of business discontinuation in efficiency-based economies. The aforementioned reasons make the study of entrepreneurship in Peru particularly relevant, especially regarding the rationale behind starting up and shutting down a business. This paper represents the first systematic effort to provide, from an experimental perspective, some insights about the characteristics of the entrepreneurs that could be linked to their entrepreneurial nature.

While the concept of development is closely related to improvements in education and health programs, as well as in civil rights (Sen, 2006), taking advantage of a strong economic growth also represents an opportunity to improve the entrepreneurs' income. Wennekers et al. (2005) show a strong correlation between entrepreneurship and development in a sample of 36 countries, including Peru. In this booming context, and with an increase in the credit supply for small and medium enterprises (SMEs), entrepreneurs have an enabling environment to start a potentially profitable business and to contribute to the economic growth, by creating their own employment, investing capital and generating jobs, and promoting future growth through innovation (Evans \& Leighton, 1989; Johnson \& Parker, 1996; Audretsch, 2007; Arrighetti \& Vivarelli, 1999).

By definition, an entrepreneur is a person who, regardless of the amount of capital invested, is in the process of starting a business or has started one within the past 3.5 years. ${ }^{3}$ Furthermore, the relatively small average value of assets, the number of workers hired and the widespread use of payments in cash, make us believe that we are talking about an informal business (Feld, Frey, \& Torgler, 2006). Arguably, among other important characteristics of the entrepreneurs, their preferences towards risk, their intrinsic satisfaction of conducting business (the so-called joy of winning) and the overconfidence in their abilities, are among the most interesting features to examine. We use tools developed by experimental economics and behavioral economics to analyze those features exploiting a sample of necessity-driven entrepreneurs ${ }^{4}$ in Lima.

\footnotetext{
3 It's important to mention that entrepreneurship comprises agents who are in the process of starting a business or are in the nascent stage of the same, in contrast to the micro, small or big businessmen who are measured by the size of their company. However, one feature is not exclusive of the other, because a person may be an entrepreneur and also a large or small businessperson.

4 The Global Entrepreneurship Monitor (GEM) distinguishes between necessity-driven and opportunitydriven entrepreneurs. The former are typically self-employed and set aside a large capital investment, thus creating new jobs and innovative ideas, while the latter tend to be younger, more educated, have more working experience, invest even more capital and exhibit less risk aversion (Caliendo \& Kritikos, 2009).
} 
Our working hypotheses include:

1. Entrepreneurs are risk lovers: Kihlstrom and Laffont (1979) propose, from a theoretical point of view, that agents with lower risk aversion have a greater propensity to make a venture that those who can't deal with risk so easily. Elston, Harrison and Rutström (2005) find evidence supporting the proposition stated above. However, if we would find that entrepreneurs are risk averse, we could argue that this feature could be one of the reasons for entrepreneurs to leave the market.

2. Entrepreneurs overestimate their business: The intrinsic joy of winning respect to future business flows causes entrepreneurs to invest high levels of initial capital. Because entrepreneurs made no previous assessments of the project and are unaware of the period in which the capital invested will be recovered, they perceive the nascent stage of the business as a loss, which encourages them to close their business sooner than expected (according to Serida, Morales, \& Nakamatsu (2012), 5.1\% of all enterprises in our country do not continue). ${ }^{5}$

3. Entrepreneurs overestimate their abilities: Because entrepreneurs overestimate their abilities, they are more likely to enter the market faster. Given that they value their abilities as superior to those required by the market (despite being below-average), in a competitive market, they are vulnerable to potential big losses.

We are also interested in the tax effects on the entrepreneurs' decision to leave the market. In March 2012, the Peruvian Minister of Finance announced the issue of a working plan to modify the Peruvian Tax Code, with the intention to reduce informality and mitigate tax evasion, being the main evaders the independent businesses. This announcement included the following proposals: increase the tax burden via the criminalization of tax evasion, implementation of control systems and promotion of a greater formalization. This change in tax legislation raised the question of how the entrepreneurs perceive the retention of a percentage of their earnings, and whether this

In Peru, for each necessity-driven business generated, two are opportunity-driven (Serida, Morales, \& Nakamatsu, 2012).

5 In Peru, the business discontinuation rate has fallen from $10.4 \%$ in 2008 to $9.3 \%$ in 2010 and $5.1 \%$ in 2011. While this figure may seem relatively low, Peru ranks higher than the average rate of discontinuation in efficiency-based economies (4.3\%) on the GEM sample and ranks very close to the rate shown in resourcebased economies (5.7\%). As mentioned in the GEM, it should be emphasized that not always discontinuing a business involves a failure and that $21 \%$ of entrepreneurs who had discontinued a business said the business continued to operate with the same activities and $24 \%$ mentioned that continued operating with other activities. Some of the reasons given for shutting down the business are financial problems (lack of profitability or difficulty getting financing), which account for $53 \%$ of Peruvian business closures in 2011. Other reasons include the sale of the business, planned shutdown, new job and other business (17\%), and personal reasons (28\%). The circumstantial reasons account for $2 \%$. 
condition may be crucial in choosing a less profitable path involving no payment of a tax. Although this article does not analyze the quantitative impact of these measures on the entrepreneurs, it does examine the response of this group to different retention rates in an experimental fashion. Thus, we expect to know the levels of effort that the entrepreneurs would be willing to exert for a fee, subject to different retention rates. On this regard, we propose the following (fourth) hypothesis:

4. If the business rate of return is sufficiently high, the taxed entrepreneur will be willing to put more effort than the non-taxed one with lower returns. Thus, it is expected to confirm that the tax assessment is not incorporated in the analysis of opening a business, which only takes into account the profits associated with the gross capital gain, so that taxes are not perceived properly.

The remainder of the article is organized as follows. The second section presents the conceptual framework related to the methodological tools used in the analysis. The third section explains the methodology implemented to test our hypotheses. The fourth section describes the data used. The fifth section discusses our main results. The sixth section concludes, and the last section suggests some extensions for future work.

\section{CONCEPTUAL FRAMEWORK ${ }^{6}$}

\section{a. Preferences towards risk}

Brockhaus (1980) divides the risk of an entrepreneurship in three components: the risk preference of a potential entrepreneur, the probability of failure of a specific project, and the perceived consequences of failure. Because of these factors, Liles (1974) suggests that the potential entrepreneurs should carefully evaluate the specific risks associated with their business and then determine if they are willing to bear those risks. This suggests that the risk attitude of a person is one of the key variables in examining the choice between undertaking a venture or getting a salaried job (Caliendo, Fossen, \& Kritikos, 2006), and also the choice between staying as an entrepreneur or going back to a fulltime job.

There are two prevailing theories used to estimate risk preferences in an experimental context: the expected utility theory (EUT) and the prospect theory (in its standard version and in its cumulative version--CPT). Under EUT, risk aversion ${ }^{7}$ is given by the curvature of the utility function, which, in turn, is captured by a single parameter (Galarza \& Power, 2012). On the other hand, under CPT, risk preferences are affected by three parameters: the concavity of the utility function, the nonlinear probability

\footnotetext{
6 Appendix 1 summarizes some of the work on the issues discussed herein.

7 If a subject prefers a safe alternative ("X") to any other risky alternative whose expected value is "X", then we say that this subject is risk averse.
} 
weighting $^{8}$ (weighting function), and the level of loss aversion compared with gains (valuation function) (Kahneman \& Tversky, 1979).

Under EUT, it is often assumed the following constant relative risk aversion (CRRA) ${ }^{9}$ utility function:

$$
U(X)=\frac{X^{1-r}}{1-r}
$$

where " $r$ " represents the CRRA coefficient, whose values may fall into one of the following categories:

a. If $r=0$, then the subject is risk neutral (we would have a linear utility function), meaning that the subject gets the same utility having " $X$ " with certainty as having " $X$ " with risk.

b. If $r>0$, then the subject is risk averse (concave utility function). It means that the subject prefers to have " $X$ " with certainty than " $X$ " with risk.

c. If $r<0$, then the subject is risk loving (convex utility function), meaning that the subject prefers to have " $X$ " with risk rather than " $X$ " with certainty.

The analysis of the individuals' risk preferences is one of the most studied topics, partially due to its potentially significant economic impact. ${ }^{10}$ For instance, a risk adverse person may decide not to undertake a profitable but risky investment, which, in the absence of risk transfer mechanisms, such as insurance, may imply the adoption of a suboptimal accumulation strategy (Galarza \& Carter, (2011). It could also happen that if a risk adverse person already started a business, then his risk aversion will not let him stay too long in business without earnings, making him leave the market too soon.

Similarly, given that an entrepreneur makes decisions in an uncertain environment, in principle, only people who can bear high risks may become entrepreneurs, given its previous employment status ${ }^{11}$ (Caliendo, Fossen, \& Kritikos, 2006). In the same vein, Hinz and Jungbauer-Gans (1999) find that entrepreneurs who were previously unemployed manage much smaller ventures and Stewart et al. (1999) report a positive correlation between risk-taking behavior and the size of the enterprises, i.e., the larger

8 There is substantial experimental evidence suggesting that subjects tend to overestimate small probabilities and underestimate large probabilities, a fact that implies that the weighting function is concave for small probabilities and convex for large ones, on the gain domain (Camerer and Ho, 1994; Gonzalez and

Wu, 1999; Tversky and Kahneman, 1992).
9 The relative risk aversion is measured by the following expression: $R R A=-\frac{U(x)^{\prime \prime}}{U(x)^{\prime}} x$.

${ }^{10}$ See Galarza and Carter (2011), Dyer and Sarin (1982), Hansen and Singleton (1983), Elston et al. (2005), among others.

${ }_{11}$ The opportunity cost of the decision to become an entrepreneur of the unemployed is significantly lower than the opportunity cost for taking this decision while employed (see Amit, Muller \& Cockburn, 1995). 
the business, the larger the entrepreneur's risk. Moreover, the small-business owners showed an attitude towards risk much more similar to that displayed by a company manager.

We will use binary lotteries to measure risk preferences, method that is explained in Section 3.

\section{b. Joy of Winning}

Holt y Sherman (1994) introduced a type of auction that identifies the so-called "joy of winning" and show evidence of certain types of judgment errors. The auction design was performed to identify the origin of the "winner's curse", which refers to the belief that some people lose money by participating in a common-value auction, because the winner of the first-price auction often regrets his victory since he overestimated the value of the item. The authors argue that there are two explanations for this result: a judgment error and the joy of winning.

The judgment error occurs when bidders are not aware that they should bid similar amounts to the estimated value of the item, conditional on their desire to win, since this event is informative. In particular, the informative event reports to those who had the highest bid and if the information given was identical for all bidders, then everyone adopted a symmetrical bid function and their estimations were the highest among the bidders. With that happening, is likely that the individual overestimated the item, which could be applied to entrepreneurs overestimating their chances of succeeding in their new businesses.

On the other hand, the winner's curse may be also explained by the joy of winning an auction. That is, since the winners are the ones most likely to lose, if subjects have a higher utility from winning, given their winnings, then people with "joy of winning" could place a higher bid just to increase their chances of winning. This result may arise even when bidders make a correct calculation of the value of the item (Elston et al., 2005).

This article analyzes whether the sample of necessity-driven entrepreneurs in Metropolitan Lima is affected by the joy of winning, which could lead them to an overestimation of the value of undertaking an entrepreneurship and, ultimately, to leave the market because of the business failure (or below-expectation performance).

\section{c. Overconfidence and Markey Entry}

Camerer and Lovallo (1999) design an experiment on market entry decision where payments, conditional on entering, depend on how many others entered the market and on their relative skills. This experimental design is based on the assumption made by March and Shapira (1987), which explains why new businesses fail within a few years: the "hubris hypothesis" (Roll, 1986), which suggests that decision makers may have a tendency, fueled by their overconfidence in their skills to manage the business, their pride or their own personal motives, to pay too much for the companies they are acquiring. 
It is said that, when this hypothesis is present, the economic gains to the acquiring firm are not even the primary motivation in the acquisition of the new firm.

As noted by Elston et al. (2005), allowing the relative profitability in the market to be determined by a ranking of skills that involves a series of quiz questions is crucial in this design. Thus, subjects with greater hierarchy of skills would earn more money if they enter the market, and subjects with a lower hierarchy of skills would earn less money, and could even lose part of the initial endowment provided to start the experiment. Those individuals who choose not to enter the market are allowed to keep their endowments. It is noteworthy that any subject can know his score on the test before entering the market, so this decision is determined in part by the subject's belief on his skill level, relative to others'.

We thus expect to elucidate the Lima entrepreneurs' level of confidence in their abilities, as a potential factor that may explain business failure.

\section{d. Taxes}

The traditional tax analysis defines tax as the coercive payment made by economic agents to the government, and for which they don't receive directly a service in return. We analyze the effect of income tax on entrepreneurs' profits in an experimental setting. Taxes will decrease profits in a proportional way: subjects who earn more will be levied at higher rates (Urrunaga, 2001).

The Peruvian tax code considers that companies with annual revenues of up to $S / .525,000$, with fixed assets (excluding land and vehicles) of $S / .126,000$, total purchases of up to $S / .525,000$ and less than 10 employees, are subject to a special tax regime. Once they exceed those thresholds, they are subject to an income tax rate that is at least 1.5 percentage points higher than the rate previously paid. Assuming that the entrepreneur owns the capital required to run his business and leases it to generate profits, the return on his project will be:

$$
(1-T) * R=P_{k}(r+d)
$$

where $T$ is the tax rate on profits/income, $R$ is the return on the business, $r$ is the real interest rate, $d$ the depreciation, and $P_{k}$ the price to lease the capital. From equation (2) follows that any tax increase will require a higher return to carry out the investment; otherwise, it will not be attractive to allocate capital to the project. Since financial theory shows that there is no difference between accounting and economic income when evaluating the impact on the projects' net present value, the analysis of this article will focus on the accounting income generated by the enterprise to investors, since it takes into account the liquidity constraints, capital needs, and the effect of taxes on the profitmaximizing process of entrepreneurs. ${ }^{12}$

\footnotetext{
12 Appendix 2 explains the preference to use an economic utility rather than an accounting utility.
} 
On the other hand, authors such as Feld, Frey and Torgler (2006) suggest that tax incentives have different effects on people's behavior, depending on their risk preferences, assuming constant relative risk aversion. They, thus, propose that risk lovers agents are more likely to evade tax lien, whereas risk adverse subjects are more likely to pay their taxes, even though they may not perceive any tangible benefits from paying.

Finally, Fochmann and Weinmann (2011) design an experiment to elicit the agents' perception towards taxation. They compare the effort levels exerted by taxed and untaxed agents. To do this, subjects are asked to perform a task, without time constraint, for which each individual $i$ earns a wage $w$ per each unit produced of a good, $X_{i}$ (folding envelops). At the same time, their income will be taxed by $\tau$, so that the tax burden equals $\tau\left(X_{i}\right)$ and the net income will be $w X_{i}-\tau\left(X_{i}\right)$. The production cost (the subject's disutility of effort) depends on the number of goods produced, $c\left(X_{i}\right)$, and is assumed to be a convex function:

$$
\frac{\partial c\left(X_{i}\right)}{\partial X_{i}}>0 y \frac{\partial^{2} c\left(X_{i}\right)}{\partial X_{i}^{2}}>0
$$

Because each individual decides independently how many envelopes they will "produce", the level of output depends on the time spent in the laboratory $\left(t_{i}\right)$ and the effort they put into the activity $\left(e_{i}\right)$. It is expected that entrepreneurs will not perceive correctly the taxes, which would lead to a bias that can be corrected with the variable, $\hat{\tau}$, which represents the perception of the tax burden. Defining the bias as $\Delta \tau=\hat{\tau}-\tau$, we say that the bias is overestimated (underestimated) when $\hat{\tau}$ is higher (lower) than $\tau$. Assuming that individuals decide their labor supply given their expected payoff, they maximize:

$$
\pi_{i}\left(e_{i} t_{i}\right)=w e_{i} t_{i}-\hat{\tau}\left(e_{i} t_{i}\right)-c\left(e_{i} t_{i}\right)=w e_{i} t_{i}-\tau\left(e_{i} t_{i}\right)-\Delta \tau\left(e_{i} t_{i}\right)-c\left(e_{i} t_{i}\right)
$$

When we normalize the time spent in the laboratory $\left(t_{i}=1\right)$, we get the first-order necessary condition as a function of effort:

$$
w-\frac{\partial \tau £}{\partial e_{i}}=\frac{\partial c\left(e_{i}\right)}{\partial e_{i}}=w-\frac{\partial \tau}{\partial e_{i}}-\frac{\partial \Delta \tau}{\partial e_{i}}
$$

At the optimum, the marginal revenue equals the marginal cost of effort. Given the assumptions for the cost function, the optimal effort will increase with wages. But the reaction to the real marginal tax depends on how far the perceived tax, $\hat{\tau}$, is from the real tax, $\tau .{ }^{13}$ Moreover, the difference between the real rate and the perceived rate should not be constant but must increase until the bias is maximum, and then must converge to the actual value of the lien. If we find that the bias exists, we can say that entrepreneurs do not perceive properly the tax burden (Fochmann \& Weimann, 2011).

13 Bartolomé (1995) and Chetty et al. (2009) show that the difference is due to the undervaluation of taxes so that the magnitude of the bias in equation (4) has a negative sign. 


\section{METHODOLOGY: EXPERIMENTAL DESIGN}

Experimental sessions were conducted between January and June of 2013, in the districts of San Juan de Lurigancho, El Agustino, La Victoria, Jesus María, Miraflores, Lince, San Borja and Cercado de Lima ${ }^{14}$. Invitations to participate were sent to several organizations that train entrepreneurs, including: MiBanco, Embark Peru, Training Workshop and Family Research (in Spanish: Taller de Capacitación e Investigación Familiar (TACIF)) and Educational Services El Agustino (in Spanish: Servicios Educativos El Agustino (SEA)), being the last two the ones that provided the subjects for our experiments. Individuals were randomly chosen and sample was split into a treatment group (consisting of necessity-driven entrepreneurs) and control group (staff of the Universidad del Pacífico and workers hired by necessity-driven entrepreneurs). Our sample consists of 56 people in the treatment group and 46 in the control group. For the treatment group, experiments were conducted in houses owned by the entrepreneurs and in their businesses. Experiments for the control group were run at the premises of the Universidad del Pacífico and at the employees' workplace. Appendices 3 and 4 show the instructions given to both groups.

During the sessions, subjects were assisted individually to fill the questionnaires, and to complete the risk and joy of winning experiments. The market entry and the overconfidence experiments were conducted in groups of five, while the perception-oftax experiments were conducted in groups of three.

Each experimental session was conducted in three stages. In the first stage, ${ }^{15}$ individuals signed a consent form and then completed a questionnaire about their personal and business characteristics (see Appendix 5 for the instructions). In the second stage, participants performed three tasks to elicit the level of risk aversion (Appendix 6), the joy of winning (Appendix 7), and overconfidence and market entry (Appendix 8). In the third stage, they performed the task on the effect of taxes (Appendix 9). Payment for participation was made after the completion of the third stage. Experiments lasted approximately an hour. Sessions were conducted separately between the control and treatment groups, and participants' average winnings are $S / .10$ (ten Nuevos Soles).

\footnotetext{
${ }^{14}$ It is noteworthy that, while individuals who took part in the experiment were evaluated in these districts, many of them work in different areas of Lima: San Juan de Lurigancho, Villa María del Triunfo, Jesus María, El Agustino, San Juan de Miraflores, among others.

${ }^{15}$ As part of our protocol, people were assured that none of the data collected will be used for other purposes beyond academia.
} 


\subsection{MEASURING PREFERENCES TOWARDS RISK}

We follow the procedure suggested by Holt and Laury (2002). Appendix 6 shows the instructions used.

\subsection{Measuring THE JoY OF WinNing}

We follow Holt and Sherman's (1994) procedure. They developed an auction game in which it is possible to separate the effects of the joy of winning and of judgment errors by performing three cases. Appendix 7 shows the instructions used.

\subsection{Measuring Overconfidence and Markey Entry}

We follow the methodology suggested by Moore and Cain (2003), who propose a set of questions that are divided into simple and complex. Appendix 8 shows the instructions used.

\subsection{MeASURING SENSIBILITY TOWARD TAXES}

As we saw in section 2, because the time has been normalized ${ }^{16}$, we will focus only on the level of effort (which is additively time-independent). We follow the methodology suggested by Fochmann and Weimann (2011). Appendix 9 shows the instructions used and Appendix 10 develops the methodology a bit further.

\section{DATA AND DESCRIPTIVE STATISTICS}

The total sample involves 102 individuals (56 in the treatment group and 46 in the control group), 59\% of whom are women. The typical subject is 37.5 years old, $62.1 \%$ of the sample has completed college education $(51.6 \%$ in a technical college and $10.5 \%$ in a university), $32.6 \%$ has completed high school and $5.3 \%$ has completed primary school. Moreover, $47.4 \%$ of them are married and the average household size is 4 people.

Within the treatment group (necessity-driven entrepreneurs), the average age is 40.6 years, $73 \%$ are women, $65.5 \%$ has higher education $(49.1 \%$ with technical education and $16.4 \%$ with a college degree), $25.5 \%$ has completed high school and $9 \%$ have completed primary school. Also, entrepreneurs have an average household size of 4 people and $49.1 \%$ of them are married. Moreover, in most cases, the business accounts

\footnotetext{
16 Since the experiments were conducted in situ, entrepreneurs did not incur in a big opportunity cost of participation. On the other hand, when we met the entrepreneurs in their own houses, the sessions were scheduled as part of the programming they have with NGOs, so that they had already planned not going to work during that period of time.
} 
for an important part of the household income. ${ }^{17}$ In this sample, $43 \%$ of household incomes over the past year are at most $S / .12,000,7 \%$ are in the range between $S / .24,001$ and $S / .30,000$, and $4 \%$ are in the range between $S / .42,001$ to $S / .48,000$. As a result, the average annual income in the treatment group is $S / .35,076$.

In addition, the average age of the entrepreneurship is 10.28 months, with the oldest having 36 months. The highest concentration of business is in the retail sale of clothing, groceries and restaurants. Also, most entrepreneurs have liquidity constraints occasionally, but $70 \%$ did not experience liquidity constraints at the time of the study. The main source of capital to start their businesses is savings (38\%), followed by loans (28\%) (from a business incubator: $11 \%$, and from banks: 17\%). Moreover, most entrepreneurs finance their current activities via bank loans (51\%) and reinvestment of their profits (50\%).

Regarding the control group, $40 \%$ are women, the average age is 33.5 years, $57.5 \%$ of the sample has higher education $(55 \%$ with technical education and $2.5 \%$ with a college degree), and $42.5 \%$ has completed high school. In addition, $45 \%$ of individuals are married and the average household size is 3 people. Income information from the control group was not gathered.

\section{RESULTS}

\subsection{Preferences towards Risk}

Figure 1 shows the proportion of subjects who chose the safe lottery (vertical axis) in each of the 10 decision rows (horizontal axis). The prediction for a risk neutral subject (red line) is to choose the safe lottery in the first 4 rows and then switch to the risky lottery. As can be seen: (i) there is a sizeable level of risk aversion for both the treatment group (green line, with triangles) and the control group (blue line, with circles), since the curves lie to the right of the prediction for a risk-neutral person, and (ii) the treatment group shows less risk aversion than the control group: in each row, the percentage of people who chose the safe lottery is lower in the treatment group than in the control group (in the latter group, the safe option was chosen $61 \%$ of the times, while this figure is $51 \%$ for the former group).

\footnotetext{
${ }_{17}$ Household income is defined includes all income received by members of the family living in the same household (including dependents):wages, tips, interest payments and dividends, student loans, parent support, social pension, alimony, child support and more.
} 
Figure 1. Percentage of times the safe lottery was chosen

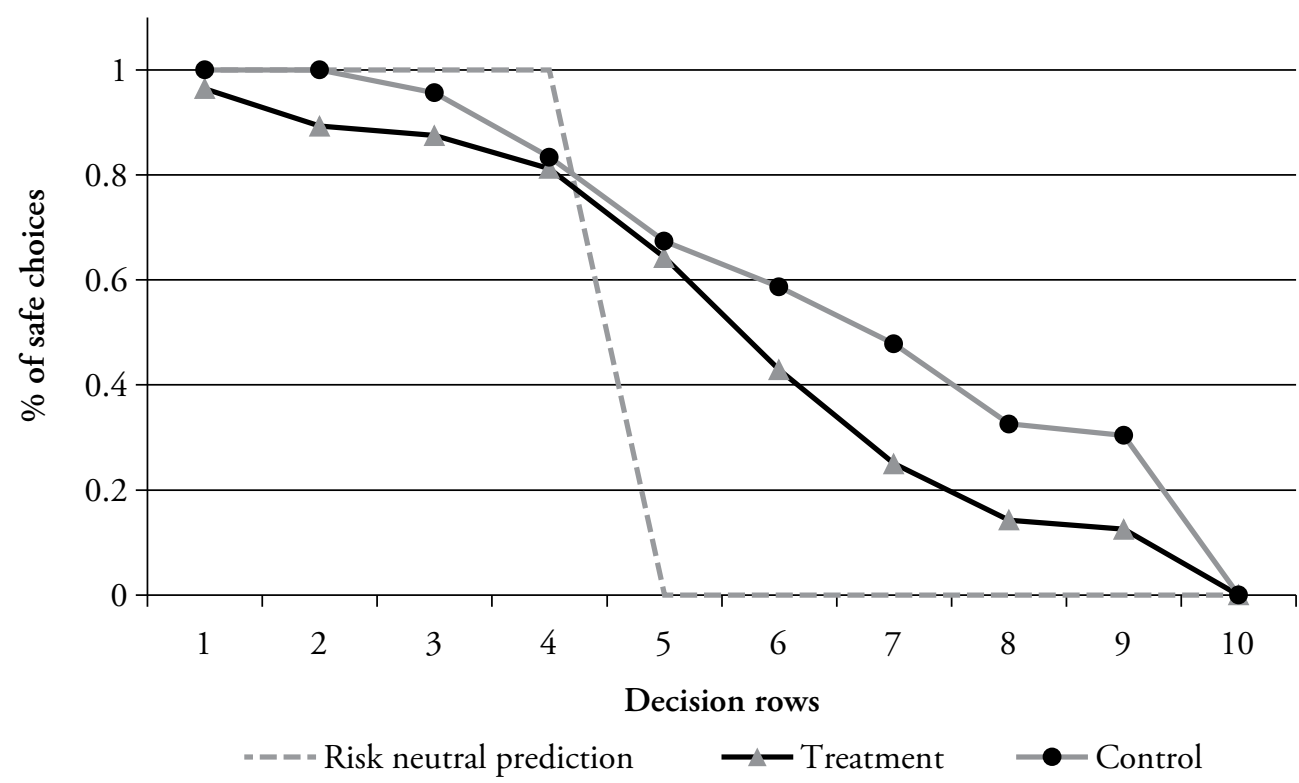

Examining the data in more detail, we see that, in the case of the control group (46 people), 31 people are risk averse $(67.40 \%), 6$ are risk neutral (13.04\%), and 9 are risk lovers $(19.56 \%)$, while in the treatment group (56 people), 36 people are risk averse $(64.30 \%), 10$ are risk neutral $(17.85 \%)$ and 10 are risk lovers $(17.85 \%)$. The choices made imply an average CRRA of 1.1244 for the control group (dependent workers), denoting a high degree of risk aversion, and a CRRA coefficient of 0.4785 for the treatment group, which indicates a moderate degree of risk aversion. Both figures are statistically different from each other at the $1 \%$ of significance $(\mathrm{p}$-value $=0.0079)$ using the " $\mathrm{T}$ " test and $10 \%(\mathrm{p}$-value $=0.0747)$ using the Wilcoxon test (Mann-Whitney). These statistically significant differences remain unchanged when we compare the average number of times that both groups chose the safe lottery (test " $\mathrm{T}$ " with p-value $=$ 0.0191 and Wilcoxon test with p-value 0.0747).

Summing up, the risk aversion indicators presented earlier show a group of necessitydriven entrepreneurs who are risk averse. These findings are contrary to the classical theory of Kihlstrom and Laffont (1979), which states that entrepreneurs are risk-lovers who are more likely to engage in ventures than people who can't tolerate risks. Similarly, our results also differ from those by Elston et al. (2005), who find that full-time entrepreneurs have a low risk aversion. The findings on risk aversion are the first evidence that could suggest why entrepreneurs leave the market: because they are risk averse, 
and they can't thus tolerate staying without earnings (or too much earnings) for a long period of time, which is what usually happens during the first stages of a new business. Therefore, due to its risk aversion, they may leave the market sooner than expected.

To conclude this section, it is important to note that the theoretical reason for the results (risk averse entrepreneurs) to be different from those found in the existing literature (risk-loving entrepreneurs) may be that our sample only includes necessity-driven entrepreneurs. This type of entrepreneur, unlike the opportunity-driven entrepreneur, probably would want to work for a company as a dependent worker, although it is likely they will not be hired for the job they want because of their low educational level, so they will end up being self-employed and starting a business of their own. In this sense, essentially, the entrepreneurial nature of the necessity-driven entrepreneurs seems to be very similar to that of a dependent worker (they are more risk averse) but different from an opportunity-driven entrepreneur (who are not afraid of taking risks when finding an excellent business opportunity).

In other words, we think that necessity-driven entrepreneurs are sufficiently less risk averse (than non-entrepreneurs) to start a business of their own (due to necessity), but sufficiently more risk averse (than opportunity-driven entrepreneurs) to leave the market sooner than expected when they don't see enough earnings realized during the initial stages of their new businesses. While this leads us to reject our hypothesis that entrepreneurs would be risk lovers, it is interesting to show that there is not just one type of entrepreneur and that the nature of the entrepreneurs in our sample doesn't fit the previous theory (Kihlstrom \& Laffont, 1979) nor the previous empirical findings (Elston et al., 2005). This is important because our results provide insights about the nature of entrepreneurs in Lima and would eventually help design better policies to support this important sector of the Peruvian economy, so that entrepreneurs don't just leave the market before their business actually start earning profits. Probably, a tax scheme that supports entrepreneurs during the first three years of their business could help reduce the high business discontinuation rate in our country.

\subsection{JoY OF WINNING}

As shown in Appendix 7, the experimental design that measures the "joy of winning" is based on the completion of three bids: no curse; the winner's curse; and the loser's curse. Each bid evaluates different behaviors, as mentioned in Section 3 (Methodology).

For the purpose of this article, we focus on the first bid, the No Curse, as it allows us to measure, in isolation, the joy of winning. ${ }^{18}$ This happens when the bidding is of the

${ }^{18}$ In the "Winner's curse" treatment, the judgmental error can be confounded with the joy of winning; therefore, the "Loser's curse" treatment can be used to only identify the judgmental error. Remember that in the "Winner's curse" the rational bidder (who does not suffer from judgmental errors) will bid lower 
same amount for the rational and the naive bidder, so that way the standard judgmental error plays no role in bidding. According to Holt and Sherman (1994), the predicted bid for risk neutral subjects in the No Curse treatment is S/.7.00. To know whether necessity-driven entrepreneurs in Lima exhibit the "joy of winning", their bids must then exceed such predicted bid.

We find that the average bid in the No Curse treatment group is S/. 9.30, compared with the S/. 9.64 in the control group and we cannot reject the null hypothesis that such difference is statistically significant. The most common value in both groups is S/.10. Figure 2 depicts the histogram of the observed bids in the No Curse treatment group and the prediction for risk neutral subjects according to Holt and Sherman (1994). $70.2 \%$ of the individuals in this group submitted bids greater than the risk-neutral subject prediction, which shows that our typical necessity-driven entrepreneur exhibit the "joy of winning".

Figure 2. Percent of bids in the treatment group

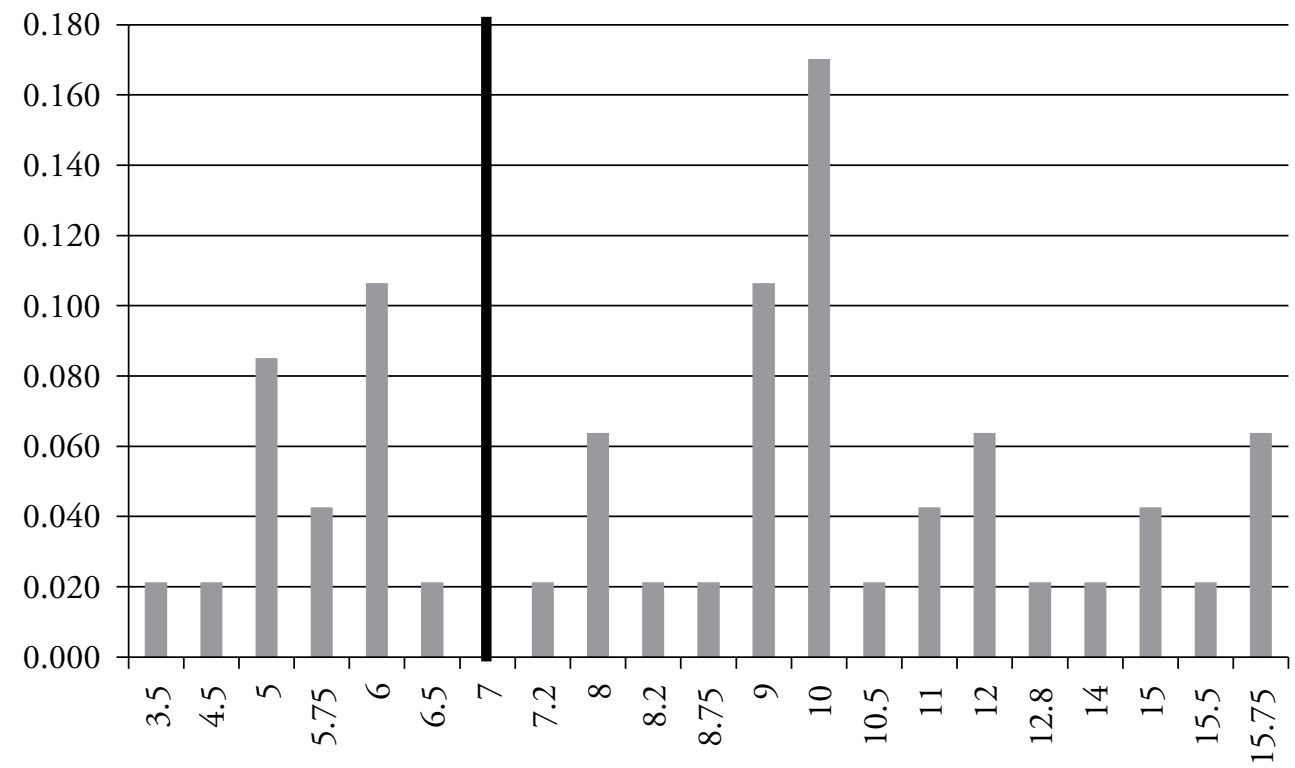

Regarding the control group (Figure 3), 72.7\% of individuals submitted bids above S/.7. Thus, both the control and the treatment groups show joy of winning. 
Figure 3. Percent of bids in the control group

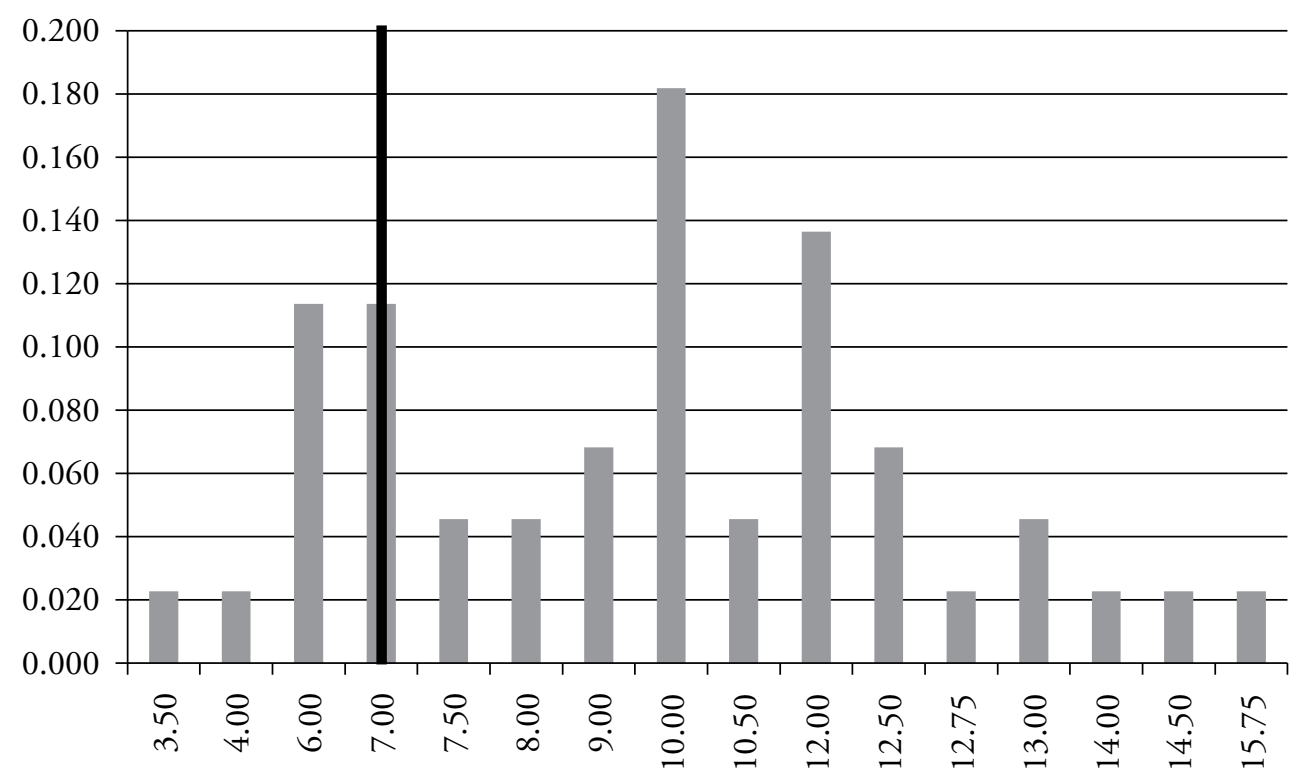

This joy of winning detected in our sample of entrepreneurs might be, together with the risk aversion finding, one of the reasons why entrepreneurs leave the market. Now that we found the joy of winning in our sample, it is likely that entrepreneurs overestimated their chances of succeeding in their new businesses, which could lead them, ultimately, to leave the market because of a business failure.

\subsection{Overconfidence and Market Entry}

During this experiment, participants could choose between a fixed payment of 10 Nuevos Soles and compete for a grand prize of 35 Nuevos Soles (turning down the fixed payment). Two thirds of the participants (66.1\%) in the treatment group (entrepreneurs) chose to compete for the grand prize and turned down the fixed payment. From those who competed for the prize, $36 \%$ answered only one question correctly, $57 \%$ of entrepreneurs failed all 3 questions, and only $7 \%$ answered correctly two questions. Because there was no clear winner in the market, those who performed better were asked to guess how many people had entered the market. If any of them guessed the exact number of people that had entered the market, then that person was awarded the grand prize. In case of a tie, they had to flip a coin.

In contrast, the percent of dependent workers (control group) who decided to enter the hypothetical market is largely higher $(89.5 \%)$. However, the results are similar to that of the treatment group in terms of the correct answers: $24 \%$ of the control subjects 
only answered one question correctly, 3\% answered two questions correctly, and the rest $(73 \%)$ did not answer any questions correctly. Moreover, $21.4 \%$ of entrepreneurs who entered the hypothetical market answered correctly the number of individuals with whom they will compete in their group versus $18.4 \%$ of correct answers in the control group. Individuals in the treatment group who answered incorrectly failed, on average, by 0.5 , while the control group failed, on average, by 1 .

Although when individuals choose the variable payment instead of the fixed payment (subject to their knowledge) in the beginning of the experiment we may guess that they are overconfident in their abilities, we wanted to confirm such hypothesis by adding another question. Subjects were thus asked about the position they think they would rank among a group of 100 similar entrepreneurs. $40 \%$ of entrepreneurs expected to be among the top ten (against 24\% in the control group), 58\% felt they would be in the top quintile (against 39\% in the control group), 23\% placed themselves in the fourth quintile (the highest concentration of individuals within the control group was in the second quintile, with $53 \%$ of them) and $8.9 \%$ of the participants responded that they could be in the bottom quintile (versus $5.3 \%$ in the control group). Thus, despite showing a slightly risk-averse behavior, individuals exhibit overconfidence in their abilities, which may have encouraged them to enter the market quickly and invest in their enterprise. With overconfidence present, there should not be surprising that entrepreneurs will overvalue their businesses and their chances of succeeding, thereby leading to a potential failure, which ultimately would push them to leave the market.

\subsection{TAXES}

As mentioned earlier, the experiment on taxes involved giving subjects envelopes to be filled with folded letters, and then sealed. This task had no time limit and participants were split into three groups. The first one (T1) received a payment of 9 cents per envelope, the second one (T2) received a payment of 12 cents but with a $25 \%$ withhold in income, and the third one (T3) received a payment of 18 cents per envelope and a retention of $50 \%$ of income. The goal of this experiment is to measure the effort level of participants, given by the number of sealed envelopes.

On average, in the treatment group (entrepreneurs), in T1, 18.24 envelopes were sealed; in T2, 30 envelopes; and in T3, 20.6 envelopes, versus the control group (dependent workers), which sealed 13.9 envelopes in T1, 15.8 in T2, and 13.1 in T3. These results for the treatment group (T1 sealed fewer envelopes than T2 and T3) are consistent with the results by Fochmann and Weimann (2011). Overall, our results show that tax retention itself does not discourage the effort whenever there is a promise of a higher pay for more effort. However, if the tax rate is sufficiently high, T3 participants might be tempted to work less and end the experiment before the T2 group, but after T1 (this is shown by the average value of the effort—sealed envelopes). 
Since the net payment is exactly the same for each group ( 9 cents of Nuevo Sol), we find evidence of bias in the tax equation (equation (4)), which shows that entrepreneurs perceive profits as being more important than tax rates, up to a certain point, where they perceive that the tax rate is too high, point in which they will see as being more important than profits.

The effect on our necessity-driven entrepreneurs leaving the market seems clear: if they perceive taxes as being too high, adding to the equation that they are risk averse, then they will be more prone to leave the market as soon as they can, after seeing little returns on their businesses and having to pay taxes even if they make modest earnings.

\section{CONCLUSION}

Our analysis of the characteristics of entrepreneurs in Metropolitan Lima shed some light to understand their decision to open and close a business. Our main three findings are: (i) necessity-driven entrepreneurs in Lima are risk averse; they experience joy of winning, so they tend to overvalue their businesses; (ii) they often overestimate their skill levels, which is shown by the marked difference between the high-performing hierarchy in which they place themselves and their poor performance answering correctly the questionnaire, and their decision to abandon the fixed payment and try to win the grand prize when entering the market; (iii) there are distortions in the way entrepreneurs perceive tax burdens, from which we can conclude that individuals receive a payment for the effort independently of the tax assessment. It thus appears that they only consider the utility that generates the gross pay for the requested work, up to a certain point where the marginal tax rate (on effort) is too high.

Those results suggest that the high discontinuation rate of businesses in Peru (those which shut down before 3.5 years) may be the result of a thorough assessment of their own abilities and the challenges they face when entering a competitive market. Our story is as follows: their joy of winning and overconfidence in their own abilities make them enter the market without a thorough analysis of the business value and their competition in the market, probably overvaluing the business and their chances of success. If we add the risk aversion to the menu, then we have entrepreneurs that won't tolerate staying with modest profits (or with negative profits) for a long period of time. Finally, if we add a tax scheme that will charge their businesses even when they make little earnings, they would not have more incentives to stay in the market. There should be no surprise, then, that entrepreneurs leave the market sooner than expected.

Based on our results, some policy-making recommendations are directly related to the entrepreneurs. Entrepreneurs would benefit from a better understanding of the challenges they face at the initial stages: patience and a solid knowledge of the market is needed before they can see large and sustained profits. Teaching entrepreneurship seems crucial to sort out the difficulties found along the way. There are currently training 
programs offered by NGOs and several governmental offices. Also, entrepreneurs may find useful to tell which personal traits affect their business decisions: are they risk averse? Are they overconfident? Do they have an excessive joy of winning? Being aware of those features may help them identify when these features are interfering with their business decisions and/or performance. The development of entrepreneurship in Peru may also benefit from a special tax scheme that would enable them to stay in the market for longer periods of time, thus allowing them to reach their potential.

It is important to remember that although the experiments we run aim to increase our understanding of a specific group of entrepreneurs in Lima; the conclusions presented should be taken with caution, as the results cannot be fully extrapolated. To which extent our results apply to other regions within Peru? To answer this question, we need to conduct similar studies in other regions, controlling for population density and sociodemographic characteristics.

\section{EXTENSIONS}

As mentioned earlier, we would like this paper to stimulate further research on the entrepreneurial sector. While there are several non-governmental organizations, institutes and universities ${ }^{19}$ that promote new talent through the provision of goods and services, economic research and behavioral studies about this sector are still scant. ${ }^{20} \mathrm{An}$ interesting venue for future research is the comparative analysis of the undergraduate students' decision-making about becoming a dependent or independent worker (for example, between public or private undergraduate students). It could also be interesting to compare undergraduate students with a high propensity to start their own businesses with necessity-driven entrepreneurs.

Finally, our analysis could be improved by conducting some further econometric analysis, for which new data are needed. For example, a regression examining the impact of education, income or years of experience, among other variables, on the decision of becoming an entrepreneur (Appendix 11 preliminary explores this path). This type of analysis will allow us to see the joint effect of several preferences over the probability of becoming an entrepreneur, thus ensuring more robust results. Lastly, a full understanding of the nature of entrepreneurship would need a dynamic analysis of the problem.

\footnotetext{
19 Among them, TACIF, SEA, Emprende Perú, Emprende UP, Lima Valley, and Wayra Perú.

${ }^{20}$ Global Entrepreneurship Monitor is working on the psychological factors that affect the decision of becoming an entrepreneur in Peru.
} 


\section{APPENDICES}

\section{Appendix 1. Summary of the literature review on entrepreneurs}

\begin{tabular}{|c|c|c|c|c|c|}
\hline Characteristic & Author(s) & Country & $\begin{array}{c}\text { Period of } \\
\text { analysis }\end{array}$ & Methodology & Result \\
\hline $\begin{array}{l}\text { Risk } \\
\text { aversion }\end{array}$ & $\begin{array}{l}\text { M. Caliendo, } \\
\text { F. Fossen and } \\
\text { A. Kritikos } \\
(2006)\end{array}$ & Germany & $2004-2005$ & Logit & $\begin{array}{l}\text { - In general, people with less } \\
\text { risk aversion are more likely } \\
\text { to become self-employed. } \\
\text { However, sensitivity analysis } \\
\text { reveals that this is only } \\
\text { true for people coming out } \\
\text { from a regular job, while } \\
\text { for unemployed people, risk } \\
\text { attitudes do not play a role in } \\
\text { their decision process. }\end{array}$ \\
\hline Risk aversion & $\begin{array}{l}\text { M. Caliendo, } \\
\text { and A. } \\
\text { Kritikos } \\
(2009)\end{array}$ & Germany & 2003 & Logit & $\begin{array}{l}\text { - There is a strong connection } \\
\text { between motives, survival rates } \\
\text { and entrepreneurial growth. } \\
\text { - Business creation, both } \\
\text { because of opportunity and } \\
\text { necessity, have higher } \\
\text { survival rates than firms } \\
\text { performed only by necessity, } \\
\text { though both face the same } \\
\text { unemployment duration prior. }\end{array}$ \\
\hline Risk aversion & $\begin{array}{l}\text { Galarza } \\
(2009)\end{array}$ & Peru & 2009 & $\begin{array}{l}\text { Standard lab } \\
\text { experiments } \\
\text { (lotteries) } \\
\text { and linear } \\
\text { regression }\end{array}$ & $\begin{array}{l}\text { - Higher education is the single } \\
\text { most important feature related } \\
\text { to risk preferences. } \\
\text { - There is a connection between } \\
\text { cognitive abilities and risk } \\
\text { behavior. }\end{array}$ \\
\hline Risk aversion & $\begin{array}{l}\text { J. Elston, G. } \\
\text { Harrison and } \\
\text { E. Rutström } \\
(2005)\end{array}$ & USA & $2004-2005$ & $\begin{array}{l}\text { Standard lab } \\
\text { experiments } \\
\text { (lotteries) } \\
\text { and Linear } \\
\text { regression }\end{array}$ & $\begin{array}{l}\text { - The full-time entrepreneurs } \\
\text { are less risk averse than non- } \\
\text { entrepreneurs. } \\
\text { - The part-time entrepreneurs } \\
\text { are more risk averse than non- } \\
\text { entrepreneurs. }\end{array}$ \\
\hline Risk aversion & $\begin{array}{l}\text { M. Schneider } \\
(2005)\end{array}$ & USA & 2004 & $\begin{array}{l}\text { Standard lab } \\
\text { experiments } \\
\text { (lotteries) } \\
\text { and linear } \\
\text { regression }\end{array}$ & $\begin{array}{l}\text { Entrepreneurs show less } \\
\text { risk averse compared to } \\
\text { their counterparts, non- } \\
\text { entrepreneurs. }\end{array}$ \\
\hline $\begin{array}{l}\text { Judgment errors } \\
\text { and joy of } \\
\text { winning }\end{array}$ & $\begin{array}{l}\text { J. Elston, G. } \\
\text { Harrison and } \\
\text { E. Rutström } \\
(2005)\end{array}$ & USA & 2004-2005 & $\begin{array}{l}\text { Standard lab } \\
\text { experiments } \\
\text { and linear } \\
\text { regression }\end{array}$ & $\begin{array}{l}\text { - The full-time entrepreneurs } \\
\text { have a considerable joy of } \\
\text { winning. } \\
\text { - There is no evidence that } \\
\text { entrepreneurs exhibit systematic } \\
\text { judgment errors about the } \\
\text { profitability of the offer. }\end{array}$ \\
\hline
\end{tabular}




\begin{tabular}{|c|c|c|c|c|c|}
\hline Characteristic & Author(s) & Country & $\begin{array}{c}\text { Period of } \\
\text { analysis }\end{array}$ & Methodology & Result \\
\hline $\begin{array}{l}\text { Judgment errors } \\
\text { and joy of } \\
\text { winning }\end{array}$ & $\begin{array}{l}\text { M. Schneider } \\
(2005)\end{array}$ & USA & 2004 & $\begin{array}{l}\text { Standard lab } \\
\text { experiments } \\
\text { and linear } \\
\text { regression }\end{array}$ & $\begin{array}{l}\text { - Entrepreneurs do not show } \\
\text { any statistically significant } \\
\text { difference about judgment } \\
\text { errors when compared to non- } \\
\text { entrepreneurs. } \\
\text { - Entrepreneurs and non- } \\
\text { entrepreneurs show joy of } \\
\text { winning. However, the size } \\
\text { effect is larger for entrepreneurs. }\end{array}$ \\
\hline $\begin{array}{l}\text { Overconfidence } \\
\text { and market } \\
\text { entry }\end{array}$ & $\begin{array}{l}\text { J. Elston, G. } \\
\text { Harrison and } \\
\text { E. Rutström } \\
(2005)\end{array}$ & USA & $2004-2005$ & $\begin{array}{l}\text { Standard lab } \\
\text { experiments } \\
\text { and linear } \\
\text { regression }\end{array}$ & $\begin{array}{l}\text { The full-time entrepreneurs and } \\
\text { non-entrepreneurs show no } \\
\text { systematic overconfidence skills. }\end{array}$ \\
\hline $\begin{array}{l}\text { Overconfidence } \\
\text { and market } \\
\text { entry }\end{array}$ & $\begin{array}{l}\text { P. Koellinger, } \\
\text { M. Minniti } \\
\text { and C. } \\
\text { Schade } \\
(2005)\end{array}$ & $\begin{array}{l}18 \text { countries: } \\
\text { Argentine, } \\
\text { Canada, } \\
\text { Denmark, } \\
\text { Finland, } \\
\text { Germany, } \\
\text { Hungary, } \\
\text { India, Israel, } \\
\text { Italy, Japan, } \\
\text { New Zealand } \\
\text { Poland, } \\
\text { Portugal, } \\
\text { Russia, } \\
\text { Singapore, } \\
\text { South Korea, } \\
\text { Sweden and } \\
\text { USA. }\end{array}$ & 2001 & $\begin{array}{l}\text { Linear } \\
\text { regression }\end{array}$ & $\begin{array}{l}\text { - People rely heavily on their } \\
\text { perceptions rather than } \\
\text { objective probabilities. } \\
\text { - People evaluate their business } \\
\text { with overconfidence so they } \\
\text { overestimate their chances of } \\
\text { success. }\end{array}$ \\
\hline Taxes & $\begin{array}{l}\text { J. Cullen and } \\
\text { R.Gordon } \\
(2007)\end{array}$ & USA & $1964-1993$ & $\begin{array}{l}\text { Linear } \\
\text { regression }\end{array}$ & $\begin{array}{l}\text { - "Animal spirits" are not } \\
\text { the only factor affecting } \\
\text { entrepreneurship rates; taxes } \\
\text { and business cycle factors also } \\
\text { matter. } \\
\text { - A cut in personal tax rates } \\
\text { reduces business activity. }\end{array}$ \\
\hline Taxes & $\begin{array}{l}\text { L. Feld, } \\
\text { B.Frey and } \\
\text { B.Torgler } \\
(2006)\end{array}$ & Switzerland & 2006 & $\begin{array}{l}\text { Controlled } \\
\text { Field } \\
\text { experiments }\end{array}$ & $\begin{array}{l}\text { The tax payment compliance } \\
\text { increases significantly when } \\
\text { individuals discover that } \\
\text { compliance is rewarded for their } \\
\text { honesty. }\end{array}$ \\
\hline Taxes & $\begin{array}{l}\text { B. Torgler } \\
(2007)\end{array}$ & Switzerland & 2001-2003 & $\begin{array}{l}\text { Controlled } \\
\text { Field } \\
\text { experiments }\end{array}$ & $\begin{array}{l}\text { Moral suasion has practically no } \\
\text { effect on taxpayer compliance. }\end{array}$ \\
\hline
\end{tabular}




\section{Appendix 2. Difference between Economic and Accounting Profits}

Let's assume a company that sells a product at some unit price with a production function $f(K)$, which only depends on capital, which is increasing and has diminishing returns. The capital depreciation time is 1 and the interest rate is $r$. Then, the economic utility $\pi_{E}$ will be:

$$
\pi_{E}=f(K)+(1+r) K
$$

If the tax would be included firms would maximize (1-T) where "T" are taxes, which is the same as maximizing $\pi_{E}$. So the optimal capital would be determined as:

$$
f^{\prime(K)}=(1+r)
$$

Moreover, the accounting profit $\pi_{C}$ will also depend on the debt or leverage "b" and the depreciation is different than 1 (higher under accelerated depreciation or investment tax credits):

$$
\pi_{C}=f(K)-(r b+d) K
$$

Companies will pay "T" taxes therefore accounting profits will be: $(1-T) \pi_{C}$. If we proceed to subtract the corresponding tax payments $\pi_{C}$ from economic profits we will have:

$$
\pi=(1-T) f(K)-(1+r-T(r b+d)
$$

Where " $\pi$ " is the accounting profit after taxes $\pi=(1-T) \pi_{C}$. If all the capital would be financed with leverage and depreciation would occur in one period $(b=1$ y $d=1)$, then the accounting profits would be equal to the economic utility.

$$
f^{\prime}(K)=\frac{1+r-T(b r+d)}{1-T}
$$

So, if the economic utility would be equal then the capital decision is equal to the one that would be taken without taxes. In other words, the $(1-T)$ factor would be suppressed. If the depreciation is greater than one, accelerated depreciation or investment tax credits would be encouraging investment.

Thus, it is preferable to consider accounting profits since they consider liquidity constraints and capital needs. Also, accounting profits take into account the effect of taxes on the profit maximizing process of entrepreneurs. 


\section{Appendix 3. General Instructions for the Experimental Study}

\section{(Control group)}

\section{Welcome to this experimental study}

This is a study of decision making. For your attendance, you will earn a fixed amount of S/.3.00 (Peruvian Nuevos Soles) and a variable amount which will depend partly on luck and partly on your decisions on certain issues that will be presented later on. The instructions are simple and you will benefit greatly from following them correctly.

The problems are not designed to test you. All we want to know is what choices you would make in such situations. There is no right or wrong answer, the only right answer is the one you choose. This is the reason why the problems give the chance to win real money. All earnings will be paid in cash at the end of the experiment.

The experiment is divided into three parts.

The first part consists of some questions about you and your entrepreneurship. This information will be used only for academic purposes. Published results of our study will not allow the identification of any individual or company, or the choices you have made or someone else. It is important to say that this information will not be delivered to any other person.

The second and third parts are small decision problems in which luck can play a role. Each decision problem requires you to make a choice. This will be described in more detail when you have completed the first part of the study. Both the second and the third parts can result in additional revenue for you. Remember that these payments in the second and third will be assigned to a specific exchange rate of 0.25 (unless otherwise specified).

We expect the test will last approximately one hour. 


\section{Appendix 4. General Instructions for the Experimental Study}

\section{(Treatment group)}

\section{Welcome to this experimental study}

This is a study of decision making. For your attendance, you will earn a fixed amount of S/.10.00 (Peruvian soles) and a variable amount which will depend partly on luck and partly on your decisions on certain issues that will be presented. The instructions are simple and you will benefit greatly from following them correctly.

The problems are not designed to test you. All we want to know is what choices you would make in such situations. There is no right or wrong answer, the only right answer is the one you choose. This is the reason why the problems give the chance to win real money. All earnings will be paid in cash at the end of the experiment.

The experiment is divided into three parts.

The first part consists of some questions about you and your entrepreneurship. This information will be used only for academic purposes. Published results of our study will not allow the identification of any individual or company, or the choices you have made or someone else. It is important to say that this information will not be delivered to any other person.

The second and third parts are small decision problems in which luck can play a role. Each decision problem requires you to make a choice. This will be described in more detail when you have completed the first part of the study. Both the second and the third parts can result in additional revenue for you. Remember that these payments in the second and third will be assigned to a specific exchange rate of 0.25 (unless otherwise specified).

We expect the tests will last approximately an hour. 
Appendix 5. Questionnaire about socio-demographic variables

\section{Part 1: Some questions about you and your entrepreneurship}

In this survey, most questions are descriptive. Your answers will not be qualified. Your responses are completely confidential. Please think carefully about each question and give your best answers.

\section{Questions about your firm}

1. How old is your firm, in years?

2. What type of product or service do you provide?

3. Have you ever experienced a shortage of capital in running your firm?
a. Never
b. Rarely
c. Occasionally
d. Often
e. Always

4. Do you have a shortage of capital now?
a. Yes
b. No

5. How did you primarily finance your firm's start up? (Circle all that apply)
a. Inheritance
b. Gift
c. Credit cards
d. Earnings from another job
e. Business incubator grant
f. Private loan from a bank or person
g. Other

6. Have you ever applied for or received a business incubator grant?
Applied
a. Yes
b. No
Received
a. Yes
b. No

7. How do you finance your firm now? Enter rough percentages for each:
a. Government loans or grants
b. Private loans from banks or people
c. Credit cards
d. Earnings from another job
e. Cash from operations
f. Equity capital
g. Other 
8. What would you estimate to be the annual revenue of your firm?

9. What would you estimate to be the value of the assets of your firm?

10. What is the state and ZIP code of the main location of your firm?

\section{Questions about you}

1. What is your age?

2. What is your gender?
a. Male
b. Female

3. What is your current employment status, and that of your spouse or domestic partner? (Circle one number for each)

You Your partner

$\begin{array}{lll}\text { a } & \text { a } & \text { Self-employed only } \\ \text { b } & \text { b } & \text { Part-time employment in another firm } \\ \text { c } & \text { c } & \text { Full-time employment in another firm } \\ \text { d } & \text { d } & \text { Actively seeking employment } \\ \text { e } & \text { e } & \text { Unemployed }\end{array}$

4. What is the highest level of education you have completed?
a. Primary school
b. High school
c. Higher institute
d. University
e. Mastery
f. Doctorate

5. Are you currently:
a. Single and never married?
b. Married?
c. Separated or divorced?
d. Widowed?

6. How many people live in your household? Include yourself, your spouse and any dependents. Do not include your parents or roommates unless you claim them as dependents. 
7. Please circle the category below that describes the total amount of INCOME earned in 2003 by the people in your household (as "household" is defined in the previous question). [Consider all forms of income, including salaries, tips, interest and dividend payments, scholarship support, student loans, parental support, social security, alimony, and child support, and others.]
a. S/.12,000.00 or less
b. $S / .12,001.00-S / .18,000.00$
c. $S / .18,001.00-S / .24,000.00$
d. $S / .24,001.00-S / .30,000.00$
e. $S / .30,001.00-S / .36,000.00$
f. $S / .36,001.00-S / .42,000.00$
g. $S / .42,001.00-S / .48,000.00$
h. $S / .48,001.00-S / .54,000.00$
i. $S / .54,001.00-S / .60,000.00$
j. More than $S / .60,000.00$

\section{Appendix 6. Experiment to measure risk preferences}

\section{Part 2: Decision Task 1}

We will show you ten decisions. Every decision is a choice between the lottery "A" and the lottery "B". In each row you have to make a choice between "A" and "B".

In the black bag you can observe that there are ten balls numbered from 1 to 10 each. These balls will be used to determine the payments. These will be determined as follows: observe the decision 1: If the ball drawn is number 1, then the lottery " $\mathrm{A}$ " pays $\mathrm{S} / .4 .00$ (Peruvian soles), but if the ball drawn is a number between 2 and 10 then the lottery "A" pays S/.3.20. Moreover, the lottery "B" pays $S / .7 .70$ if the ball drawn is number 1, but pays $S / .0 .20$ if the ball drawn is a number between 2 and 10. Remember that all payments are affected by an exchange rate of 0.25 .

The other decisions are similar, except that as you progress in your decisions the largest payout odds for each lottery will continue to increase. Moreover, if you see decision 10 you can see that, if that row is selected, there is no need to remove a ball to determine your payment as each lottery gives the maximum safely. Thus, your choice in this row is to choose between $S / .7 .70$ and S/.4.00.

After you have made all your choices, you will draw a ball twice: the first ball will be used to choose one of the ten decisions made, and the second ball will determine your payment to the lottery chosen ("A" or "B") selected in the respective decision with the first ball. Thus, even though you will make ten decisions, only one of these will end up affecting your earnings, but you will not know which of their decisions will be used. 


\begin{tabular}{|c|c|c|c|c|}
\hline Decision & Lottery “A” & Lottery “B” & $\begin{array}{l}\text { Your } \\
\text { (choo } \\
\text { or " }\end{array}$ & $\begin{array}{l}\text { choice } \\
\text { se "A" } \\
\text { (B") }\end{array}$ \\
\hline \multirow[t]{2}{*}{1} & $\begin{array}{l}10 \% \text { chance of winning } S / .4 .00 \\
\text { and } 90 \% \text { chance of winning }\end{array}$ & $\begin{array}{l}10 \% \text { chance of winning } S / .7 .70 \\
\text { and } 90 \% \text { chance of winning }\end{array}$ & & \\
\hline & S/.3.20 & S/.0.20 & A & $\mathrm{B}$ \\
\hline \multirow[t]{2}{*}{2} & $\begin{array}{l}20 \% \text { chance of winning } S / .4 .00 \\
\text { and } 80 \% \text { chance of winning }\end{array}$ & $\begin{array}{l}20 \% \text { chance of winning S/.7.70 } \\
\text { and } 80 \% \text { chance of winning }\end{array}$ & & \\
\hline & S/.3.20. & S/.0.20 & A & B \\
\hline \multirow[t]{2}{*}{3} & $\begin{array}{l}30 \% \text { chance of winning } S / .4 .00 \\
\text { and } 70 \% \text { chance of winning }\end{array}$ & $\begin{array}{l}30 \% \text { chance of winning } S / .7 .70 \\
\text { and } 70 \% \text { chance of winning }\end{array}$ & & \\
\hline & S/.3.20 & S/.0.20 & A & $\mathrm{B}$ \\
\hline \multirow[t]{2}{*}{4} & $\begin{array}{l}40 \% \text { chance of winning } S / .4 .00 \\
\text { and } 60 \% \text { chance of winning }\end{array}$ & $\begin{array}{c}40 \% \text { chance of winning } S / .7 .70 \\
\text { and } 60 \% \text { chance of winning }\end{array}$ & & \\
\hline & S/.3.20. & S/.0.20 & A & B \\
\hline \multirow[t]{2}{*}{5} & $\begin{array}{l}50 \% \text { chance of winning } S / .4 .00 \\
\text { and } 50 \% \text { chance of winning }\end{array}$ & $\begin{array}{l}50 \% \text { chance of winning } S / .7 .70 \\
\text { and } 50 \% \text { chance of winning }\end{array}$ & & \\
\hline & S/.3.20. & S/.0.20 & A & $\mathrm{B}$ \\
\hline \multirow[t]{2}{*}{6} & $\begin{array}{l}60 \% \text { chance of winning } S / .4 .00 \\
\text { and } 40 \% \text { chance of winning }\end{array}$ & $\begin{array}{l}60 \% \text { chance of winning } S / .7 .70 \\
\text { and } 40 \% \text { chance of winning }\end{array}$ & & \\
\hline & S/.3.20. & S/.0.20 & A & B \\
\hline \multirow[t]{2}{*}{7} & $\begin{array}{c}70 \% \text { chance of winning } S / .4 .00 \\
\text { and } 30 \% \text { chance of winning }\end{array}$ & $\begin{array}{c}70 \% \text { chance of winning } S / .7 .70 \\
\text { and } 30 \% \text { chance of winning }\end{array}$ & & \\
\hline & S/.3.20 & S/.0.20 & A & B \\
\hline \multirow[t]{2}{*}{8} & $\begin{array}{l}80 \% \text { chance of winning } S / .4 .00 \\
\text { and } 20 \% \text { chance of winning }\end{array}$ & $\begin{array}{l}80 \% \text { chance of winning } S / .7 .70 \\
\text { and } 20 \% \text { chance of winning }\end{array}$ & & \\
\hline & S/.3.20 & S/.0.20 & A & $\mathrm{B}$ \\
\hline \multirow[t]{2}{*}{9} & $\begin{array}{l}90 \% \text { chance of winning } S / .4 .00 \\
\text { and } 10 \% \text { chance of winning }\end{array}$ & $\begin{array}{l}90 \% \text { chance of winning } S / .7 .70 \\
\text { and } 10 \% \text { chance of winning }\end{array}$ & & \\
\hline & S/.3.20. & S/.0.20. & A & B \\
\hline 10 & $100 \%$ chance of winning S/.4.00. & $\begin{array}{c}100 \% \text { chance of winning } \\
\text { S/.7.70. }\end{array}$ & A & B \\
\hline
\end{tabular}

Decision row chosen by the first ball:

Second ball that determines payment:

Earnings: ( 


\section{Payment guide}

\begin{tabular}{|c|c|c|c|c|}
\hline Decision & Lottery "A" & Lottery "B" & $\begin{array}{l}\text { Your c } \\
\text { (choo } \\
\text { or " }\end{array}$ & $\begin{array}{l}\text { hoice } \\
\text { e "A" } \\
B \text { ") }\end{array}$ \\
\hline 1 & $\begin{array}{l}\text { S/.4.00 if throw of die is } 1 . \\
\text { S/.3.20 if throw of die is } 2-10 \text {. }\end{array}$ & $\begin{array}{l}\text { S/.7.70 if throw of die is } 1 . \\
\text { S/.0.20 if throw of die is } 2-10\end{array}$ & A & B \\
\hline 2 & $\begin{array}{l}\text { S/.4.00 if throw of die is } 1-2 . \\
\text { S/.3.20 if throw of die is } 3-10 \text {. }\end{array}$ & $\begin{array}{l}\text { S/.7.70 if throw of die is } 1-2 . \\
\text { S/.0.20 if throw of die is } 3-10\end{array}$ & A & B \\
\hline 3 & $\begin{array}{l}\text { S/.4.00 if throw of die is } 1-3 . \\
\text { S/.3.20 if throw of die is } 4-10 \text {. }\end{array}$ & $\begin{array}{l}\text { S/.7.70 if throw of die is } 1-3 . \\
S / .0 .20 \text { if throw of die is } 4-10\end{array}$ & A & B \\
\hline 4 & $\begin{array}{l}S / .4 .00 \text { if throw of die is } 1-4 . \\
S / .3 .20 \text { if throw of die is } 5-10 \text {. }\end{array}$ & $\begin{array}{l}S / .7 .70 \text { if throw of die is } 1-4 . \\
S / .0 .20 \text { if throw of die is } 5-10\end{array}$ & A & B \\
\hline 5 & $\begin{array}{l}\text { S/.4.00 if throw of die is } 1-5 . \\
\text { S/.3.20 if throw of die is } 6-10 \text {. }\end{array}$ & $\begin{array}{l}S / .7 .70 \text { if throw of die is } 1-5 . \\
S / .0 .20 \text { if throw of die is } 6-10\end{array}$ & A & B \\
\hline 6 & $\begin{array}{l}S / .4 .00 \text { if throw of die is } 1-6 . \\
S / .3 .20 \text { if throw of die is } 7-10 \text {. }\end{array}$ & $\begin{array}{l}S / .7 .70 \text { if throw of die is } 1-6 . \\
S / .0 .20 \text { if throw of die is } 7-10\end{array}$ & A & B \\
\hline 7 & $\begin{array}{l}\mathrm{S} / .4 .00 \text { if throw of die is } 1-7 . \\
\mathrm{S} / .3 .20 \text { if throw of die is } 8-10 \text {. }\end{array}$ & $\begin{array}{l}S / .7 .70 \text { if throw of die is } 1-7 . \\
S / .0 .20 \text { if throw of die is } 8-10\end{array}$ & A & B \\
\hline 8 & $\begin{array}{l}\text { S/.4.00 if throw of die is } 1-8 . \\
\text { S/.3.20 if throw of die is } 9-10 \text {. }\end{array}$ & $\begin{array}{l}S / .7 .70 \text { if throw of die is } 1-8 . \\
S / .0 .20 \text { if throw of die is } 9-10\end{array}$ & A & B \\
\hline 9 & $\begin{array}{l}\text { S/.4.00 if throw of die is } 1-9 . \\
\text { S/.3.20 if throw of die is } 10 .\end{array}$ & $\begin{array}{l}\text { S/.7.70 if throw of die is } 1-9 . \\
\text { S/.0.20 if throw of die is } 10 .\end{array}$ & A & B \\
\hline 10 & $\mathrm{~S} / .4 .00$ if throw of die is $1-10$. & $\mathrm{S} / .7 .70$ if throw of die is $1-10$. & A & B \\
\hline
\end{tabular}


Appendix 7. Experiment to determine the existence of judgment errors and joy of winning

\section{Part 2: Decision Task 2}

You will have the opportunity to bet to earn money. Your offer can be any number as long as it is not too large that it results in a certain loss. We will tell you the maximum amount.

You will take a card from the deck to determine a value. If the value is less than your offer, then you will get the extra money. The money you receive will be equal to 1.5 times the value, but your offer will be subtracted from this.

You will be given three opportunities to bid, but only one will be selected for the final payment. This is done randomly. Since you may have a loss, you will be given an additional amount of money up front, plus your profits. This is an amount that will be between S/.5 and S/.15 (Peruvian soles) and a card from the deck will be taken to determine that value now.

Losses are subtracted from this amount, but you will be paid all the rest. If you do not have losses, you will be paid your profits and also this additional amount of money. Remember that the final payment is subject to an exchange rate of 0.25 . The three opportunities differ in the range of values that can be drawn from the deck of cards:

- The first time the value is extracted between $S / .3 .50$ and $S / .10 .50$.

- The second time, the value will be extracted between $S / .4$ and S /. 15.

- The third time, the value will be extracted between $S / .3$ and $S / .6$.

Additional amount of money:

Please write down your three bids here:

Bid 1: (maximum bid is S/. 15.75)

Value 1:

Bid 2: (maximum bid is S/. 22.50)

Bid 3: (maximum bid is S/. 9) Value 2:

Value 3:

We will fill in the remainder after you have drawn the cards.

Payment 1: Bid1 > Value1? [1.5 $\times$ Value1] - Bid1 = Payment 2: Bid2 > Value2? [1.5 $\times$ Value2] - Bid2 =

Payment 3: Bid3 > Value3? [1.5 $\times$ Value3 $]-$ Bid3 =

Final Payment $=($ Additional amount of money + Payment $1+$ Payment $2+$ Payment 3)*0.25 


\section{Appendix 8. Experiment to determine the existence of overconfidence and market entry}

\section{Part 2: Decision Task 3}

In this task, you will have the opportunity to earn money by deciding whether to enter or not a competitive market. Remember that your final game earnings are affected by an exchange rate of 0.25 .

You will be given S/.10 (Peruvian soles) at the beginning of the task. The task is about deciding whether to enter or not to enter the market. 4 other people will also be invited to enter or not in the same market, but it is not known in advance how many of them have accepted. In each market, only one person can get the profits. If you participate, your success will be under your control as it will depend on your ability to answer some questions. Then, all the participants will be ranked according to their successful answers to the questions. The best rated competitor will receive S/. 35 and will be the only winner.

To enter the market you must waive the $S / .10$ (participation money), which is the rate for market entry. If you decide to not enter the market, you keep the S/.10.

The ranking system. The way that the participants in this market are classified is on the basis of a general knowledge quiz. The questions are basically about mathematical reasoning. Those with a higher score will be better ranked. If there is a tie at the top, then we will throw a coin to choose one person. You will take the test after deciding to enter or not the market.

The questions will be of multiple choice. In multiple choice questions, you will need to choose the correct answer from three alternatives.

In short: If you choose to not enter the market, you will keep the $S / .10$ and will not earn more money in this task. If you choose to participate and enter the market, you will receive $S / .35$ (instead of the $S / .10$ ) if you are the highest ranked among the people entering the market (maximum 5 people per market). You will not get money from this task if you decide to enter the market and you are not the best ranked among those entering the market.

DECIDE NOW: Do you choose to enter the market and compete or do you prefer to stay out of the market?

Enter the market and waive the S/.10 participation money.

Not enter the market and keep the $S / .10$ participation money.

We have three final questions for you to answer. 
1. Please answer this question:

How many people do you think, on average, will enter the market? You will receive S/. 10 if you consider the exact number. You will receive S/. 8 if you make a mistake by one person, S/. 6 if you make a mistake by 2 , and so on. Please round up to an integer.

Choose one: 012345

2. Although there is no money for answering this question, please think about it carefully.

If we compare your answers to the questionnaire to 100 other people's answers (chosen at random): What do you think would be your rank? A rank of 1 means that you answered the questions better than anyone, a range of 50 means that you answer the questions better than one half, but not as good as the other half, and a range of 100 means that you believe that all other people answered better than you.

ANSWER:

\section{Questionnaire}

1. "The bat and the ball problem": A bat and a ball cost S/. 1.10. The bat costs S/. 1 more than the ball. How much is the ball?

10 cents 50 cents 5 cents

2. If it takes 5 machines 5 minutes to make 5 phones, how much would it take 100 machines to make 100 phones? 10 minutes 5 minutes 100 minutes

3. In a lake, there is a floating island. Every day, this island doubles its size. If it takes 48 days to the island to cover the entire lake, how many days it will take to the island to cover half of the lake?

47 days 10 days 24 days 


\section{Appendix 9. Experiment to determine tax perception}

\section{Part 3: Tax-free treatment}

By participating in this experiment you have the opportunity to make money. The payment at the end of it depends on your individual effort. Please read the following instructions carefully. If in doubt, please raise your hand and we will come to help you. The aim of this experiment is to obtain information about individual work supply. Thus, you will perform simple and real work tasks which will make you some money.

\section{Procedure}

It is important to say that communication with other participants during the experiment is not allowed. After reading the instructions you will receive letters and envelopes. Your job is to fold the letters and put them into the envelopes. Please remember to seal the envelopes.

You will determine how long you are going to work. This means that there is no time limit and you can leave the experiment at any time. Then you will be paid and allowed to leave the session.

\section{Instructions}

You will receive a payment at the end of the experiment that will depend on the number of letters folded and placed in envelopes. You will receive 9 cents for each letter. If you have folded, in average, two letters per minute then your hourly salary will be $S / .10 .80$ (Peruvian soles). If you have folded, in average, 2.5 letters per minute then your hourly salary will be $S / .13 .50$ soles. Finally, if you have folded 3 letters per minute then your hourly salary will be $S / .16 .20$. The money you earn will be paid in cash at the end of the experiment. Remember that, for the final payment, it applies an exchange rate of 0.25.

Number of envelopes sealed:

Gross Income:

Taxes: $0 \%$

Net income:

Exchange rate: 0.25

Final Payment: 


\section{Part 3: 25\% Tax treatment}

By participating in this experiment you have the opportunity to make money. The payment at the end of it depends on your individual effort. Please read the following instructions carefully. If in doubt, please raise your hand and we will come to help you. The aim of this experiment is to obtain information about individual work supply. Thus, you will perform simple and real work tasks which will make you some money.

\section{Procedure}

It is important to say that communication with other participants during the experiment is not allowed. After reading the instructions you will receive letters and envelopes. Your job is to fold the letters and put them into the envelopes. Please remember to seal the envelopes.

You will determine how long you are going to work. This means that there is no time limit and you can leave the experiment at any time. Then you will be paid and allowed to leave the session.

\section{Instructions}

You will receive a payment at the end of the experiment that will depend on the number of letters folded and placed in envelopes. You will receive 12 cents for each letter. If you have folded, in average, two letters per minute then your hourly salary will be S/.14.40 (Peruvian soles). If you have folded, in average, 2.5 letters per minute then your hourly salary will be S/.18.00 soles. Finally, if you have folded 3 letters per minute then your hourly salary will be S/.21.60. The money you earn will be paid in cash at the end of the experiment. Remember that, for the final payment, it applies an exchange rate of 0.25 .

Number of envelopes sealed:

Gross Income:

Taxes: $25 \%$

Net income:

Exchange rate: 0.25

Final Payment: 


\section{Part 3: 50\% Tax treatment}

By participating in this experiment you have the opportunity to make money. The payment at the end of it depends on your individual effort. Please read the following instructions carefully. If in doubt, please raise your hand and we will come to help you. The aim of this experiment is to obtain information about individual work supply. Thus, you will perform simple and real work tasks which will make you some money.

\section{Procedure}

It is important to say that communication with other participants during the experiment is not allowed. After reading the instructions you will receive letters and envelopes. Your job is to fold the letters and put them into the envelopes. Please remember to seal the envelopes.

You will determine how long you are going to work. This means that there is no time limit and you can leave the experiment at any time. Then you will be paid and allowed to leave the session.

\section{Instructions}

You will receive a payment at the end of the experiment that will depend on the number of letters folded and placed in envelopes. You will receive 18 cents for each letter. If you have folded, in average, two letters per minute then your hourly salary will be S/.21.60 (Peruvian soles). If you have folded, in average, 2.5 letters per minute then your hourly salary will be S/.27.50 soles. Finally, if you have folded 3 letters per minute then your hourly salary will be S/.32.40. The money you earn will be paid in cash at the end of the experiment. Remember that, for the final payment, it applies an exchange rate of 0.25 .

Number of envelopes sealed:

Gross Income:

Taxes: $50 \%$

Net income:

Exchange rate: 0.25

Final Payment: 


\section{Appendix 10. Cost function associated with treatment groups of entrepreneurs}

The behavioral analysis of entrepreneurs on which the taxation exercise was held proposes that the distance between the actual tax rate and the one entrepreneur's perceive can be measured by the difference between the marginal cost of making another envelope without tax, and one with a tax. Thus, as shown in equation (5), the disutility ${ }^{21}$ that the treatment group will perceive (the one that gets paid 9 cents over and was not imposed with any tax) is equal to the gross salary they are assigned.

$$
\begin{gathered}
w-\frac{\partial \hat{\tau}}{\partial e_{i}}=\frac{\partial c\left(e_{i}\right)}{\partial e_{i}}=w-\frac{\partial \tau}{\partial e_{i}}-\frac{\partial \Delta \tau}{\partial e_{i}}=\frac{\partial c\left(e_{i}\right)}{\partial e_{i}}=9 * e_{1}-0 \% * 9 * e_{1}=12 * e_{2}-25 \% * \\
12 * e_{2}=18 * e_{3}-50 \% * 18 * e_{3}
\end{gathered}
$$

Then, it is found that the control variable (number of sealed envelopes) differs in an aggregate substantially way between treatment groups is possible to determine the presence of bias in the taxes so that $\frac{\partial \Delta \tau}{\partial e_{i}} \neq 0 .{ }^{22}$

Thus, considering the analysis of nontax classification of this research, it is possible to propose that there isn't a prior assessment of net income that participants receive at the end of the experiment, so they will focus only on gross earnings leaving aside the tax consideration (although along with the increase in taxes said consideration will be weighted each time more given the increases).

If we also assume that the utility function takes one isoelastic form (similar to equation (5)), and can be defined in terms of the income of each entrepreneur and well-being to own intrinsic good, then it can be said that the utility increases more than proportionally to the different income levels of each group of individuals (subject to a different tax rate and assuming no prior conduct an appropriate assessment of net profits.

After noting the results of the experiment number four is possible to appreciate that individuals do not properly perceive the level of net returns so that the group, which is not taxed, makes less effort than groups with higher payment per stamped envelope subject to the inclusion of a percent withholding tax on income.

Furthermore, between these two taxed groups, those with a larger tax rate, strive less to what is possible to explain that there is a maximum distance between the maximum point of distance between the actual rate and the perceived tax rate as shown in Figure 4A.

${ }^{21}$ Disutility refers to the cost of leaving hours of leisure for work.

${ }^{22}$ Is worth mentioning that $\frac{\partial \tau}{\partial e_{i}}$ has the shape of a constant because before an increase in the number of sealed envelopes the taxed payment doesn't change. 
Then if there is a poor perception the fee will be lower so that entrepreneurs strive as if they would receive more real pay, it is also possible to argue that there is a point at which the weight of the charge becomes more significant in the individual's decision until the real value.

Figure 4A: Real versus perceived taxes

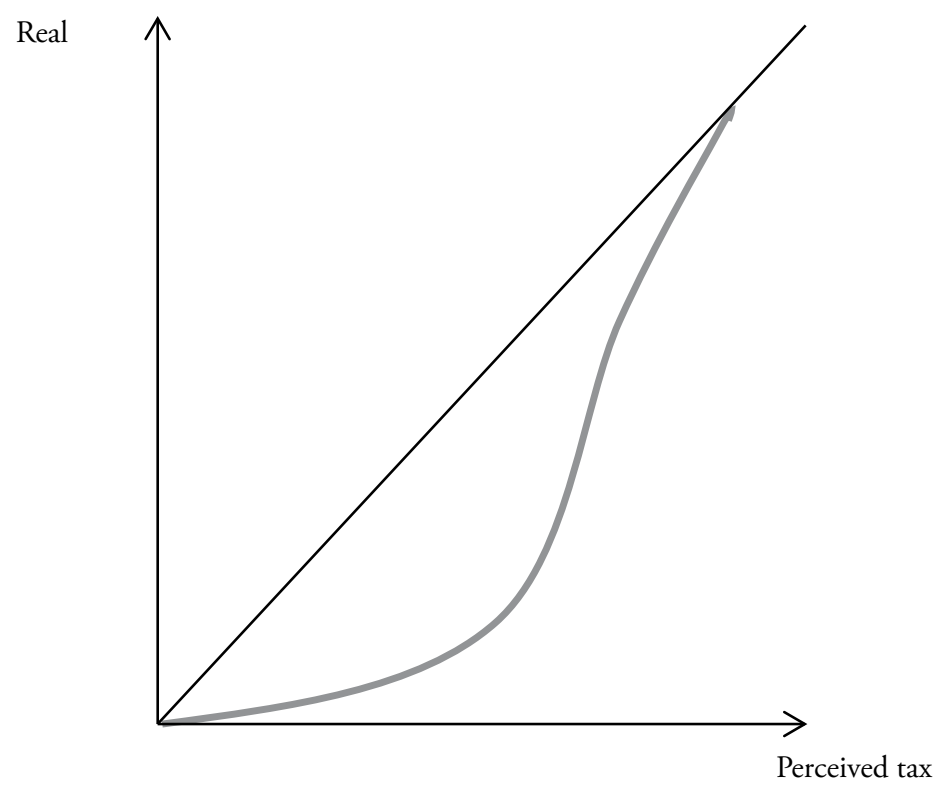




\section{Appendix 11. Binary choice model: explaining the decision to become an entrepreneur}

It seeks to assess the role of risk aversion, the joy of winning, confidence in the skills to enter the market, and perceptions of taxes as determinants of necessity-driven entrepreneurship in Metropolitan Lima. The variables included in the regression model are listed below.

Table 11A: Variables of interest in binary choice model

\begin{tabular}{l}
$\begin{array}{l}\text { Dependent Variable: } \\
\text { Entrepreneur }\end{array}$ \\
\begin{tabular}{l|l} 
Takes two values: (i) 1 , if the individual is an entrepreneur; and (ii) 0, \\
otherwise.
\end{tabular} \\
\hline
\end{tabular}

The model is summarized below:

$$
\begin{aligned}
& E\left(Y_{i} \mid X\right)=\operatorname{Pr}\left(Y_{i}=1\right)=F\left(\alpha_{1} \text { CRRA }_{1}+\alpha_{2} \text { AlGan }_{1}+G_{3} \text { ElecEnt }_{1}+\alpha_{4} \text { AutoRank }_{1}+\right. \\
& \left.\alpha_{5} \text { RespCor }_{1}+\alpha_{6} \text { Sobres }_{1}+x_{i}^{\prime} \beta+\text { error }\right) .
\end{aligned}
$$

Where $x_{i}$ is the vector of control variables, and $\mathrm{F}($.$) , the cumulative distribution$ function of a logistic distribution. The estimate assumes this type of distribution after analyzing the concentration of sample observations in the tails of the distribution using the Skewness/Kurtosis test which rejected the null hypothesis of normal distribution.

Regression results are reported below. 
Table 11B

Logit regression (Probability of being an entrepreneur)

\begin{tabular}{lcc}
\hline \multicolumn{1}{c}{ Variable } & Coefficient & Standard error \\
\hline Age & 0.0066 & 0.1479 \\
Age2 & 0.0007 & 0.0019 \\
Gender & -1.5898 & $0.5690^{* * *}$ \\
Education & 0.5056 & 0.6008 \\
CivilStatus & -0.0373 & 0.5979 \\
PeopleHome & 0.6094 & $0.2013^{* * *}$ \\
Algan & 0.6268 & 0.6317 \\
Elecent & -1.9950 & $0.8139^{* *}$ \\
Autorank & -0.0101 & 0.0114 \\
CorrectAns & 0.5650 & 0.4745 \\
CRRA & 1.6004 & $0.6226^{* *}$ \\
Overestimate & 0.0145 & 0.0226 \\
Constant & -2.6488 & 2.8381 \\
Pseudo-R2 & & 0.3358 \\
$\mathrm{~N}$ & & 102 \\
\hline
\end{tabular}

*** P-value $<0.01,{ }^{* *} \mathrm{P}$-value $<0.05,{ }^{*} \mathrm{P}$-value $<0.10$

The table shows that although not all variables of interest are significant, the signs support the hypotheses proposed. In this sense, those individuals who are risk lovers (or less risk averse), are most likely to be entrepreneurs, just as those who exhibit the joy for winning.

Regarding the choice of entering a hypothetical market, this is not decisive to increase the probability of being an entrepreneur, since most people, regardless of the group studied, showed interest in entering the market. However, while many people may have the desire to enter a market, few actually do it.

In contrast, the variables that are correlated with the probability of being an entrepreneur are the number of correct answers answered (a proxy for numeracy skills), and the location in the self-ranking. In this vein, individuals who have more correct answers or are located in the best position (within a range of 100 options 1 being the best and 100 the worst) have a higher probability of being an entrepreneur. Finally, the number of sealed envelopes, as a proxy for effort, shows that those who work harder (more sealed envelopes) are more likely to be entrepreneurs.

To get an idea of the magnitude of the effects, we calculate the marginal effects of the variables included in the table above. Thus, for example, being risk lover increases the probability of being an entrepreneur in 33 percentage points, while such probability decreases by 37 percentage points when the individual chooses to enter the hypothetical market. 


\section{REFERENCES}

Amit, R., Muller, E., \& Cockburn, I. (1995). Opportunity costs and entrepreneurial activity. Journal of Business Venturing, 10(2), 95-106. http://dx.doi.org/10.1016/0883-9026(94)00017-O

Arrighetti, A. \& Vivarelli, M. (1999). The Role of Innovation in the Postentry Performance of New Small Firms: Evidence from Italy. Southern Economic Journal, 65(4), 927-939. http://dx.doi.org/10.2307/1061285

Audretsch, D. (2007). Entrepreneurship capital and economic growth. Oxford Review of Economic Policy, 23(1), 63-78. http://dx.doi.org/10.1093/oxrep/grm001

Bartolome, C.A. (1995). Which tax rate do people use: Average or marginal? Journal of Public Economics, 56(1), 79-96. http://dx.doi.org/10.1016/0047-2727(93)01409-4

Brockhaus, R. (1980). Risk Taking Propensity of Entrepreneurs. Academy of Management Journal, 23(3), 509-520. http://dx.doi.org/10.2307/255515

Caliendo, M., \& Kritikos, A. (2009). I Want to, But I Also Need to: Starts-Ups Resulting from Opportunity and Necessity, IZA Discussion Paper Series No. 4661.

Caliendo, M., Fossen, F. M., \& Kritikos, A. S. (2006). Risk Attitudes of Nascent Entrepreneurs: New Evidence from an Experimentally-Validated Survey. IZA Discussion Paper Series No. 2168.

Camerer, Colin F. \& Lovallo, Dan (1999). Overconfidence and Excess Entry: An Experimental Approach. American Economic Review, 89(1), 306-318. http://dx.doi.org/10.1257/ aer.89.1.306

Cullen, J. \& R. Gordon (2007). Taxes and entrepreneurial risk-taking: Theory and evidence for the U.S. Journal of Public Economics, 91(7-8), 1479-1505. http://dx.doi.org/10.1016/j. jpubeco.2006.12.001

Chetty, R., Looney, A., Kroft, K., (2009). Salience and taxation: theory and evidence. American Economic Review, 99(4), 1145-1177. http://dx.doi.org/10.1257/aer.99.4.1145

Dyer, J.S. \& Sarin, R.K. (1982). Relative Risk Aversion. Management Science, 28, 875-886. http://dx.doi.org/10.1287/mnsc.28.8.875

Elston, J. A., Harrison, G. W., \& Rutström, E. E. (2005). Characterizing the Entrepreneur Using Field Experiments. Mimeo. Department of Economics, College of Business Administration, University of Central Florida.

Evans, D. \& Leighton, L. (1989). Some Empirical Aspects of Entrepreneurship. American Economic Review, 79(3), 519-535.

Feld, L. P., Frey, B. S., \& Torgler, B. (2006). Rewarding Honest Tax Payers? Evidence on the impact of rewards from field experiments. CREMA Working Paper Series No. 2006-16, Center for Research in Economics, Management and the Arts (CREMA).

Fochmann, M., \& Weimann, J. (2011). The effects of Tax Salience and Tax Experience on Individual Work Efforts in Framed Field Experiment. IZA Discussion Paper Series No. 6049.

Galarza, F. (2009). Choices under Risk in Rural Peru. MPRA Paper 17708, University Library of Munich, Germany.

Galarza, F., \& Carter, M. (2011). Risk Preferences and Demand for Insurance in Peru: A Field Experiment. Documento de Discusión No. 11-08, Centro de Investigación de la Universidad del Pacífico.

Galarza, F., \& Power, M. (2012). Economía Experimental: Nuevas metodologías para analizar el comportamiento individual. Lima: Departamento de Economía, Universidad del Pacífico.

Gonzalez, R. \& Wu, G. (1999). On the shape of the probability weighting function. Cognitive Psychology, 38(1), 129-166. http://dx.doi.org/10.1006/cogp.1998.0710 
Hansen, L. \& Singleton, K. (1983). Stochastic Consumption, Risk Aversion and the Temporal Behavior of Asset Returns. Journal of Political Economy, 91(2), 249-265. http://dx.doi. org/10.1086/261141

Hinz, T., \& M. Jungbauer-Gans (1999). Starting a Business after Unemployment: Characteristics and Chances of Success (Empirical Evidence from a Regional German Labour Market). Entrepreneurship and Regional Development, 11(4), 317-333. http://dx.doi. org/10.1080/089856299283137

Holt, C., \& Laury, S. (2002). Risk Aversion and Incentive Effects. American Economic Review, 92(5), 1644-1655. http://dx.doi.org/10.1257/000282802762024700

Holt, C. \& Sherman, R. (1994). The Loser’s Curse. American Economic Review, 84(3), 642-652.

Johnson, P. \& Parker, S. (1996). Spatial Variations in the Determinants and Effects of Firm Births and Deaths. Regional Studies, 30(7), 679-688.

Kahneman, D., \& Tversky, A. (1979). Prospect Theory: An analysis of Decision under Risk. Econometrica, 47(2), 263-292. http://dx.doi.org/10.2307/1914185

Kihlstrom, R. E., \& Laffont, J.-J. (1979). A General Equilibrium Entrepreneurial Theory of Firm Formation Based on Risk Aversion. The Journal of Political Economy, 87(4), 719748. http://dx.doi.org/10.1086/260790

Koellinger, P., M. Minniti, \& C. Schade (2005). "I Think I Can, I Think I Can”: Overconfidence and Entrepreneurial Behavior. DIW Discussion Paper No. 501.

Liles, P.R. (1974). Who Are the Entrepreneurs? MSU Business Topics, 22, 5-14.

March, J., \& Shapira, Z. (1987). Managerial Perspectives on Risk and Risk Taking. Management Science, 33(11), 1404-1418. http://dx.doi.org/10.1287/mnsc.33.11.1404

Moore, Don A., \& Cain, D. (2003). Myopic Biases in Comparative Judgment and Entrepreneurial Entry. Working Paper, Tepper School of Business, Carnegie-Mellon University.

Roll, R. (1986). The Hubris Hypothesis of Corporate Takeovers. The Journal of Business, 59(2), 197-216. http://dx.doi.org/10.1086/296325

Schneider, M. (2005). A Measure Of Entrepreneurial Risk Preference And Optimism Using Field Experiments. A thesis submitted in partial fulfillment of the requirements for the degree of Master of Arts in the Department of Economics in the College of Business at the University of Central Florida, Orlando, Florida.

Sen, A. (2006). El desarrollo como libertad. Entrevista con Amartya Sen. Cuadernos del CENDES, 23(63), 123-137.

Serida, J.; Morales, O., \& Nakamatsu, K. (2012). Global Entrepreneurship Monitor: Perú 2011. Lima: Universidad ESAN.

Smith, V. L. (2002). What is experimental economics? Fairfax, VA: Interdisciplinary Center for Economic Science, Universidad George Mason.

Stewart, W. H., W. E. Watson, J. C. Carland, \& J. W. Carland (1999). A Proclivity for Entrepreneurship: A Comparison of Entrepreneurs, Small Business Owners, and Corporate Managers. Journal of Business Venturing, 14(2), 189-214. http://dx.doi.org/10.1016/ S0883-9026(97)00070-0

Torgler, B. (2007). Tax Compliance and Tax Morale: A Theoretical and Empirical Analysis. Cheltenham, UK \& Northampton, MA, USA: Edward Elgar. http://dx.doi. org/10.4337/9781847207203

Tversky, A., \& Kahneman, D. (1992). Advances in Prospect Theory: Cumulative Representation of Uncertainty. Journal of Risk and Uncertainty, 5(4), 297-323. http://dx.doi. org/10.1007/BF00122574 
Urrunaga, R. (2001). Principios de economía pública. Lima: Departamento de Economía, Universidad del Pacífico.

Wennekers, S., Wennekers, A.V, Thurik, R., \& Reynolds, P. (2005). Nascent Entrepreneurship and the Level of Economic Development. Small Business Economics, 24(3), 293-309. http://dx.doi.org/10.1007/s11187-005-1994-8

Documento recibido el 29 de enero de 2016 y aprobado el 15 de abril de 2016 